\title{
Saudi Residences' Adaptability: How Employees Worked from Home during COVID-19 Lockdowns
}

\author{
Jamil Hijazi ${ }^{1}$, Douha Attiah ${ }^{2, *}$ \\ ${ }^{1}$ College of Architecture and Planning, King Abdulaziz University, Jeddah, Saudi Arabia \\ ${ }^{2}$ College of Human Sciences and Design, King Abdulaziz University, Jeddah, Saudi Arabia
}

Received January 11, 2021; Revised April 22, 2021; Accepted May 10, 2021

\begin{abstract}
Cite This Paper in the following Citation Styles
(a): [1] Jamil Hijazi, Douha Attiah, "Saudi Residences' Adaptability: How Employees Worked from Home during COVID-19 Lockdowns," Civil Engineering and Architecture, Vol. 9, No. 3, pp. 915 - 931, 2021. DOI: 10.13189/cea.2021.090334.
\end{abstract}

(b): Jamil Hijazi, Douha Attiah (2021). Saudi Residences' Adaptability: How Employees Worked from Home during COVID-19 Lockdowns. Civil Engineering and Architecture, 9(3), 915 - 931. DOI: 10.13189/cea.2021.090334.

Copyright $\bigcirc 2021$ by authors, all rights reserved. Authors agree that this article remains permanently open access under the terms of the Creative Commons Attribution License 4.0 International License

\begin{abstract}
During the COVID-19 pandemic, most employees in Saudi Arabia were asked to work from home. This study investigated the extent to which the indoor spaces of Saudi homes were adaptable to the concept of 'working from home' and how employees managed to work productively. A questionnaire survey was conducted among Saudi employees to gather data on their normal workplaces, home workspace designs, and work productivity. The results show that $42 \%$ of participants work in the living room, only $42 \%$ used an office desk and chair, $38 \%$ did not use any specific furniture, and $46 \%$ used mood enhancers (the addition of personalised elements to their work setup) to help them adapt better to working from home. Altogether, $63 \%$ of the participants indicated that they were satisfied with their productivity levels. Based on cross-sectional trends identified in our analyses, this paper makes recommendations for how employees who have to work from home can adapt quicker to the new situation. This includes recommendations for minor changes to existing home designs rather than rezoning or restructuring the home layout.
\end{abstract}

Keywords Pandemic, Lockdown, Working from Home, Home Design, Work Furniture, Work Productivity

\section{Introduction}

On 30 January 2020, the World Health Organization's (WHO's) director announced that the coronavirus disease
(COVID-19) is a serious global issue, and WHO member states considered options to stop the spread of the virus $[1,2]$. During the rapid outbreak, various precautions regarding the movement of people and social distancing were introduced and travel was restricted. When the virus started to spread widely on a global scale, the WHO asked organisations to warn their employees and customers that quarantines and lockdowns would be imposed if the virus started spreading in their community $[1,2]$. Countries responded differently. On 24 March 2020, the Saudi Ministry of Interior requested the majority of employees to work remotely [3]. A qualitative study of local Saudis adapting to working and studying during the pandemic in April 2020 [4] showed that $83 \%$ of employees worked during the pandemic, while $17 \%$ did not; $60 \%$ were in the private sector and $40 \%$ worked in the public sector. The sample in the study was employed in the following sectors: business and administrative jobs (24\%), education and academia (28\%), services (15\%), engineering (7\%), economy $(5 \%)$, healthcare $(4 \%)$, security $(2 \%)$, and others $(15 \%)$ [4]. A total of $64 \%$ of the overall sample indicated that they were somewhat satisfied with working from home. The study also highlighted the positive and negative aspects; positives included staying focused, time and task management, and adapting to the crisis, whereas negatives included idleness and laziness, and the challenge of managing household tasks parallel to work [4].

'Health and well-being are vitally important aspects of people-centric building design and are the roots of productivity' according to Ghaffarianhoseini et al. [5]. This 
research paper examines the readiness of homes for working from home from a different angle and reveals some important residence design-related issues. A pilot study was conducted through an online survey to measure the actual experience of 'working from home' in terms of productivity and the spatial environment's components in comparison with typical workplace setups and working routines in Saudi Arabia. A framework to analyse collected data was established, and a method for analysing the direct and indirect trends of data was designed, which resulted in the emergence of concepts with guided directions for further research to promote the necessity for designing better home workspaces. A new design term, 'mood enhancers', was introduced to describe certain measures taken to increase the quality of working from home. As an element of well-being, in this paper we define mood enhancers as additive elements that can enhance individuals' moods and reflect personal preferences for residents' well-being.

The Gensler design company studied, in depth and widely, the effects of COVID-19 on design, mainly with regard to going back to workplaces, in their regular reports and virtual seminars [6]. While most of the published literature focuses on returning to workplaces, this study aimed to examine homes and how we can increase productivity levels while working from them. According to a survey conducted in the USA by Gensler design company, only $12 \%$ of US workers want to work from home full-time, with $70 \%$ preferring to return to the workplace, but with critical changes: more space (less density) for social distancing and an assigned workspace [7]. In addition, a quantitative study investigated the advantages and disadvantages of working from home in 29 European countries during the early stages of the pandemic indicated that most people had a more positive rather than negative experience of working from home during the lockdown. Three factors represent the main advantages of working from home, work-life balance, improved work efficiency and greater work control. While the main disadvantages were home office constraints, work uncertainties and inadequate tools [8].

These measures can also improve the performance of the workplace, addressing issues of noise and distraction that were already diminishing effectiveness. Such issues require extensive study and analysis. In fact, working from home presents a unique opportunity to establish new solutions for higher productivity, creativity, and a connection to maintain a work-life balance in this new trend.

At the outset, this study aimed to examine new approaches for shaping the layouts of homes, taking into consideration the repercussions of the requirement for working from home, to design more efficient and flexible spaces. However, after the concepts highlighted by the data became clear, our suggestions focused on changing spatial aspects by using solutions involving minimal transformations that can increase productivity and satisfaction levels with minimum effort and affordability, rather than the restructuring of layouts.

\section{Materials and Methods}

\subsection{Saudi Arabia's Typical Housing Styles}

According to The General Authority of Statistics in Saudi Arabia, the majority of Saudis live in three main housing typologies: villas, apartments, and traditional houses. Apartments (including penthouses) are the most common type of housing, occupied by almost $43 \%$ of households [9]. This type refers to a self-contained residential multi-rooms unit with its own front door, kitchen, toilets, and bathrooms, in a building complex usually located in a neighbourhood with public gardens, market zones, and mosques. Penthouses are usually at the top of buildings and form an alternative living choice for those who cannot afford an actual villa but still require a residence with more than four bedrooms. Another type of common residence in Saudi Arabia is the private villa (either single floor or duplex), which represents over $28 \%$ of the total households [9]. The single villa is an individual housing unit, usually chosen by families wanting to accommodate up to three generations. They are usually constructed on approximately 2,000 square metres of land and feature a private design with three-metre-high exterior walls demarcating the boundary of the property and ensuring privacy for the family. Villas can include an outdoor separate majlis (living area), which depicts the typical style of housing in the region and includes a guest reception area for men, which is usually separated from the rest of the home to ensure that women can maintain their privacy. The other type of villa is the detached duplex, which is relatively newer in the kingdom and is smaller than the single villa but more affordable, with an average plot size of 300 square metres. These duplexes are often designed according to the typical majlis-style housing, with separate entrances for men and women. A few people (11\%) live on a separate floor in a villa [9]. Finally, primitive houses form around $18 \%$ of the Saudi housing types. These are usually vernacular with an average land size of 200 square metres and a maximum of two floors, constructed from lightweight elements and local materials. Figure 1 summarises the distribution of housing types in Saudi Arabia, and Figure 2 shows the typical layouts of duplex villas and apartments. 


\section{SAUDI ARABIA HOUSING TYPES BREAKDOWNS}



Figure 1. Distribution of housing units in Saudi Arabia for residential buildings by building type - redrawn from General Authority for Statistics, Kingdom of Saudi Arabia (2019)

\subsection{Methodology and Data Collection}

The study was conceived after the authors casually observed how people dealt with working from home in
Saudi Arabia, which led to the design of an online survey that was distributed within different community circles. To ensure high response rates, the survey was designed in Arabic and English. It included three main sections: Section 1: Normal Workplaces (pre-pandemic), Section 2: Home Workspace Design (during pandemic), and Section 3: Working Productivity (during pandemic). Table 1 below lists the survey questions and the trends or themes that were identified in the data. The following terms, pertaining to this study, were used for analysis:

Trigger: The triggers are the questions listed and coded in Table 1 that were used to help highlight trends while analysing the collected data.

Theme: A theme in this study is the main topic chosen for a selected group of triggers.

Trend: Trends were derived in direct analysis when examining the answers to direct questions in the survey.

Emerged concept: The results of all analyses (direct or indirect) by connecting and linking different triggers, themes, or trends together. The size of the linked categories is not required to be similar (trigger to trigger, or trigger to theme) [11]; any size of data can be linked to help develop new concepts. This paper resulted in one set of emerged concepts.

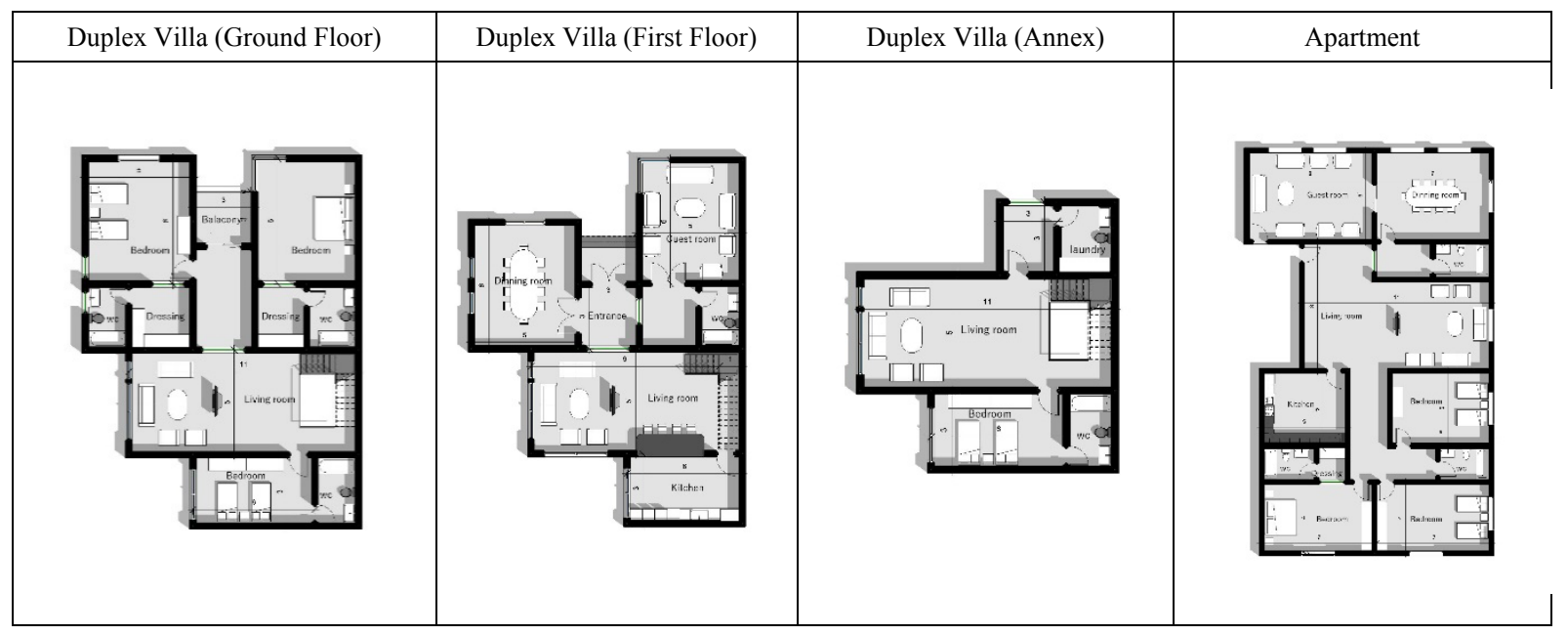

Figure 2. Typical layouts for duplex villas and apartments in Saudi Arabia - redrawn from Ministry of Housing, Kingdom of Saudi Arabia [10] 
Table 1. Survey triggers, data trends, and themes

\begin{tabular}{|c|c|c|c|c|c|c|}
\hline \multicolumn{3}{|c|}{ Question in survey (triggers) } & $\begin{array}{c}\text { Trends } \\
\text { (to look for in collected data) }\end{array}$ & Theme A & Theme B & Theme C \\
\hline \multirow{6}{*}{  } & $1-1$ & Your working fields & $\begin{array}{l}\text { Different job backgrounds and } \\
\text { employments }\end{array}$ & $\checkmark$ & $\checkmark$ & \\
\hline & $1-2$ & Your main working environment & $\begin{array}{c}\text { The type of buildings at participants' } \\
\text { workplaces }\end{array}$ & & & \\
\hline & $1-3$ & Your normal working routine & $\begin{array}{c}\text { Style of job: } \\
\text { full-time/part-time/freelance }\end{array}$ & & & \\
\hline & $1-4$ & $\begin{array}{c}\text { Your weekly working hours at your } \\
\text { main workplace }\end{array}$ & Usual working hours/routine & $\checkmark$ & & \\
\hline & $1-5$ & $\begin{array}{l}\text { At your usual work, the following } \\
\text { percentage is administrative work } \\
\text { (on-desk) }\end{array}$ & $\begin{array}{l}\text { On-desk administrative work at } \\
\text { normal workplaces }\end{array}$ & & & \\
\hline & $1-6$ & $\begin{array}{l}\text { In your usual work routine, you } \\
\text { usually spend these hours (daily) at } \\
\text { home to finish the required tasks }\end{array}$ & $\begin{array}{l}\text { Usual working hours at home after } \\
\text { work to finish tasks (normal days) }\end{array}$ & & & \\
\hline \multirow{10}{*}{ 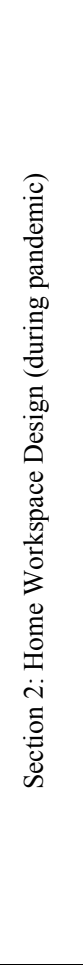 } & $2-1$ & The type of your residence & Typology - house type (Figure 1) & & $\checkmark$ & \\
\hline & $2-2$ & $\begin{array}{l}\text { In your residence, you usually work } \\
\text { at }\end{array}$ & $\begin{array}{l}\text { Locating zones in house's layout and } \\
\text { their original functions }\end{array}$ & & $\checkmark$ & $\checkmark$ \\
\hline & $2-3$ & $\begin{array}{l}\text { The size of space that you work at } \\
\text { from home, is approximately }\end{array}$ & $\begin{array}{l}\text { Approximate size of space where work } \\
\text { is usually conducted }\end{array}$ & & $\checkmark$ & \\
\hline & $2-4$ & $\begin{array}{c}\text { How many people use/share your } \\
\text { workspace at home? }\end{array}$ & Number of users in zones & & $\checkmark$ & \\
\hline & $2-5$ & $\begin{array}{l}\text { The furniture at your workplace at } \\
\text { home is }\end{array}$ & $\begin{array}{l}\text { Type of commonly used task furniture } \\
\text { at home }\end{array}$ & & $\checkmark$ & $\checkmark$ \\
\hline & $2-6$ & $\begin{array}{c}\text { Do you have a specific area or units } \\
\text { (drawers) for your stationery } \\
\text { (pens/paper)? }\end{array}$ & $\begin{array}{l}\text { Storage in the working zone } \\
\text { (stationery) }\end{array}$ & & $\checkmark$ & \\
\hline & $2-7$ & $\begin{array}{l}\text { Do you have a specific area or units } \\
\text { (drawers) for your electronic tools } \\
\text { such as printers, scanners at your } \\
\text { home workspace? }\end{array}$ & $\begin{array}{l}\text { Storage in the working zone } \\
\text { (electronics) }\end{array}$ & & $\checkmark$ & \\
\hline & $2-8$ & $\begin{array}{c}\text { Do you have water/plant elements in } \\
\text { your home workspace? }\end{array}$ & Mood enhancers & & $\checkmark$ & \\
\hline & $2-9$ & $\begin{array}{l}\text { Do you bother to add such elements } \\
\text { to add certain mood/ambiance to } \\
\text { your home workspace? } \\
\text { (artwork, candles/dim lights, music, } \\
\text { picture frames, or combination of all } \\
\text { mentioned) }\end{array}$ & Mood enhancers & & $\checkmark$ & \\
\hline & $2-8$ & $\begin{array}{c}\text { Generally, rate your satisfaction } \\
\text { level with your current workspace at } \\
\text { home }\end{array}$ & $\begin{array}{l}\text { Satisfaction levels of current zones } \\
\text { while working from home }\end{array}$ & & $\checkmark$ & \\
\hline \multirow{4}{*}{ 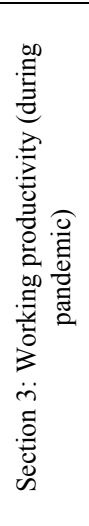 } & $3-1$ & $\begin{array}{l}\text { How many weekly hours do you } \\
\text { currently work from home } \\
\text { (lockdown period) }\end{array}$ & Unusual working hours & $\checkmark$ & & \\
\hline & $3-2$ & $\begin{array}{c}\text { Your daily continuous working hours } \\
\text { (lockdown period) in your home } \\
\text { workplace is }\end{array}$ & $\begin{array}{l}\text { Continuity of working at one place to } \\
\text { measure comfort }\end{array}$ & & & $\checkmark$ \\
\hline & $3-3$ & $\begin{array}{l}\text { You rely on the internet and } \\
\text { electronic tools to finish work from } \\
\text { home daily by the percentage of } \\
\text { (percentage of the total work done) }\end{array}$ & Demands and effect of technology & & & \\
\hline & $3-4$ & $\begin{array}{l}\text { Generally, rate your productivity of } \\
\text { working from home during the } \\
\text { curfew periods compared to your } \\
\text { normal work routine at your main } \\
\text { workspace or head-offices }\end{array}$ & $\begin{array}{l}\text { Productivity satisfaction levels } \\
\text { (general) }\end{array}$ & & $\checkmark$ & $\checkmark$ \\
\hline
\end{tabular}

For the data to result in useful findings and trends, the following steps were taken: data and questions were dealt with as triggers, and when in groups (linked together) they were mentioned as themes. Methodology steps (Figure 3): 
Direct analysis: each trigger's finding and trends resulted directly from survey questions.

Indirect analysis/cross-sectional: designed themes (groups of triggers) emerged as trends and allowed concepts to emerge.

Emerged concepts: refined linkage of trends and themes which led to conclusions and the shaping of future work recommendations.

The study relied heavily on asking employees in Saudi Arabia how they felt about working from home, and mostly reported on their working styles and the design aspects of their residences in relation to work. Two major methods (direct and indirect analyses) were followed to understand the way forward as a community to ensure that where we live is suitable for working from home, while maintaining satisfactory productivity levels.

\section{Results and Discussion}

For the pilot study, 300 responses were collected, and the online survey link was closed when a sufficient number of participants in various fields of work had responded. The fields included academia, administrative employees in general and different sectors, healthcare, airline industry including pilots and flight attendants, army employees, engineers, labourers, and lawyers.

\section{Direct Analysis}

As illustrated in Figure 3, direct trends were found when analysing each trigger (question) in Table 1. Figure 4 summarises Section 1 triggers (Table 1). It was shown that $40 \%$ of participating employees were working in administrative jobs (120 employees) and other responses varied between the mentioned fields of work in Figure 4. A total of $45 \%$ worked in offices (desk and chair used) at their original workplaces (135 employees), whereas 32\% worked in educational buildings and commonly relied heavily on desk and chair style, which brings the responses to almost $77 \%$ using a typical office setup. A total of $80 \%$ of employees (239) worked full-time, and $51 \%$ usually worked more than 34 hours per week as a routine (153 employees), including different working styles. Most of the responses indicated that office work using the typical setup at their workplaces formed their main style of work (31\%, 92 employees), and 164 showed that they normally finish tasks at home in less than four hours per week (55\%); this could indicate that the working space at home may be neglected in terms of design, as people tend to prefer finishing work tasks at the main workplace rather than taking work home. A total of 89 responded that they usually work at home 4-8 hours per week, 36 participants worked up to 12 hours at home, and only 11 indicated that they might work at home more than 12 hours per week.

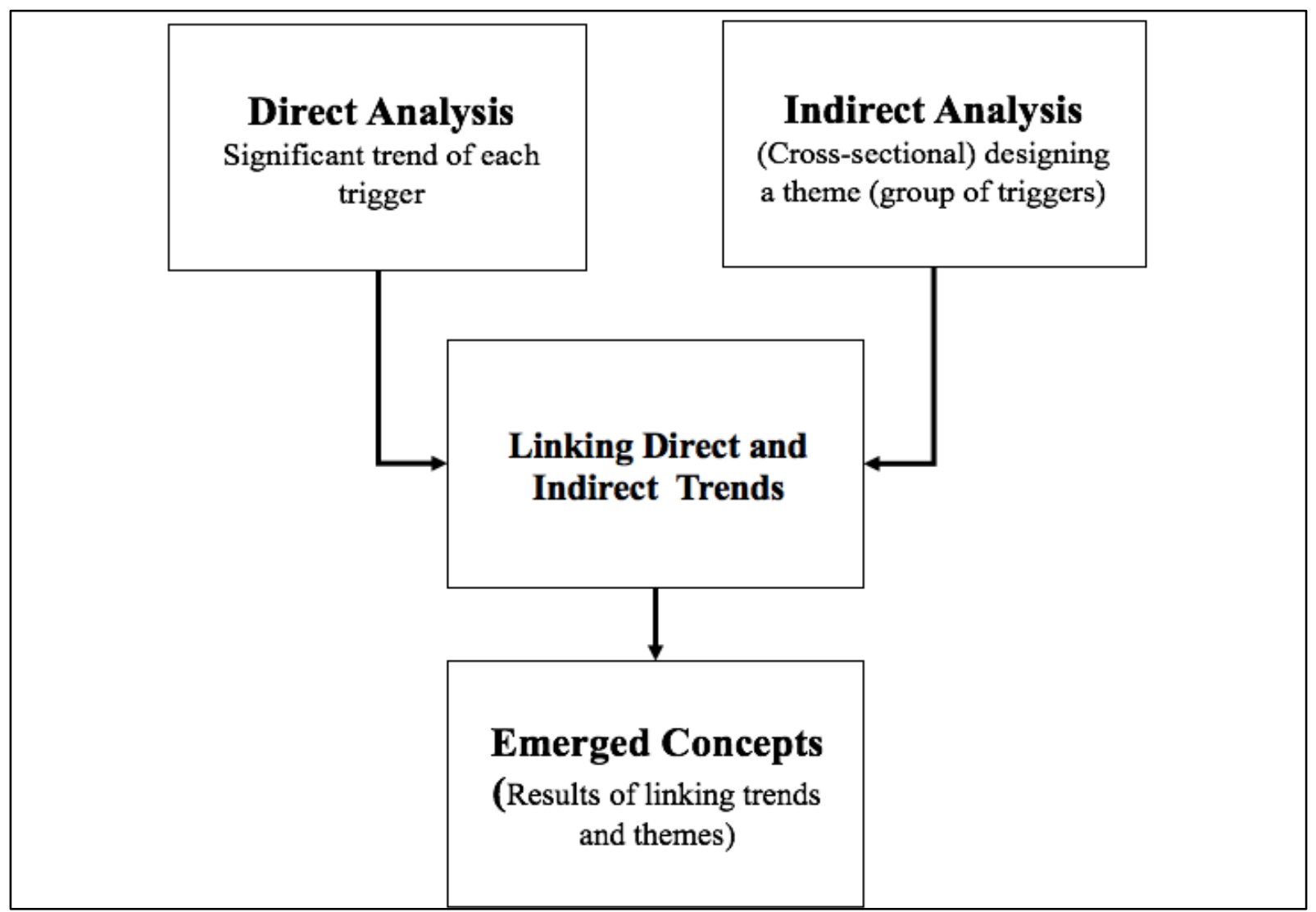

Figure 3. Steps involved as part of the research methodology 


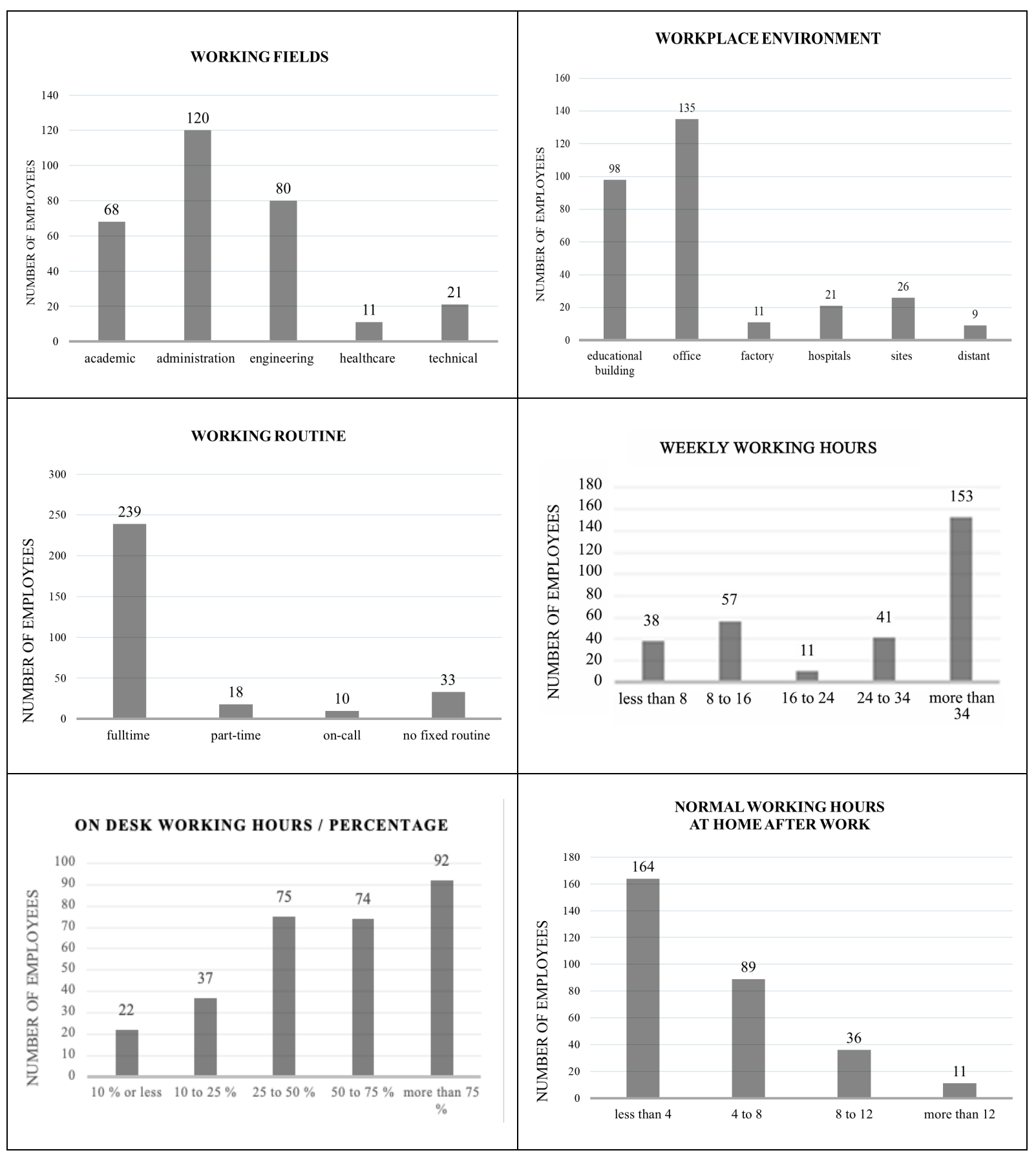

Figure 4. Section 1 trends: normal workplaces (pre-pandemic)

As for Section 2 (Table 1), Figure 6 summarises the results. The majority of employees (44\%) lived either in apartments (including penthouses) or in private villas (separate or in duplex style) (42\%), which matches the trend of residence types in Saudi Arabia (Figure 1). One important result pertains to working location in the home and can be referred to as a trend of Saudi employees during lockdowns: while $42 \%$ worked from the living room, $23 \%$ worked from their bedrooms. However, this differed, depending on the building type. Of the employees working from their villas, $52 \%$ worked from living rooms, $37 \%$ from bedrooms, $6 \%$ from dining rooms, and $5 \%$ outdoors (majlis) (Figure 5). In apartments, 54\% worked from living rooms, $28 \%$ from bedrooms, $12 \%$ from dining rooms, $8 \%$ from the reception zone, and $2 \%$ from kitchens. This shows that the lack of space in apartments causes residents to work from kitchens or reception zones. The size of the spaces or zones which employees worked in ranged from less than 10 square metres $(52 \%)$ to more than 40 square metres (4\%). A total of 200 out of 300 employees mentioned that 1 or 2 other people used their workspaces at home, followed by 84 who indicated that 2 to 5 people shared their workspaces. Another significant trend was that only 127 employees used typical office desks and chairs, 
whereas 114 worked from home with no specific furniture. This last figure should make us reconsider our requirements in our working and living styles. While 52\% of the participants indicated that they stored stationery (pens, papers) in the same workspace at home, $30 \%$ did not have a space for stationery, and $18 \%$ stored them in different places around the house. However, for larger items such as printing or scanning devices, $45 \%$ of the respondents stored them in the same zone, while a minority of $17 \%$ said they stored electronics around the home in different places. Some did not have any of these items at home (38\%). These results may depend on the situation at the original workplace or on the size of the electronic devices. In addition, when examining well-being, it was found that $64 \%$ did not have any water or plant elements in their home workspace, while $36 \%$ did. A trend emerged which showed that employees used mood enhancers and additive decorative elements, perhaps to increase their productivity and create a personal atmosphere for improved working and well-being. A total of $54 \%$ reported the use of personal framed pictures which evoke pleasant memories, candles, or dim lights, and unique art works is carefully chosen. These significant trends may account for why $62 \%$ (186 employees) were either satisfied or extremely satisfied with the design of their home workspaces (Figure 6).

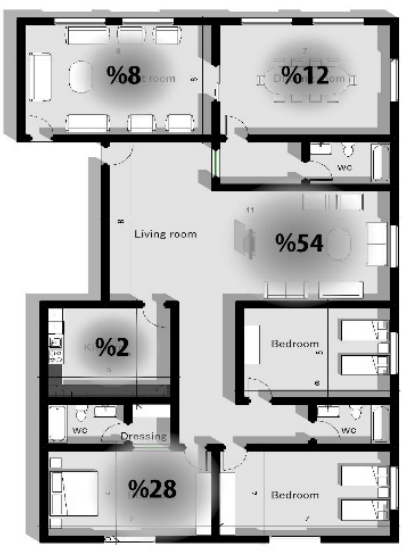

Apartment typical layout
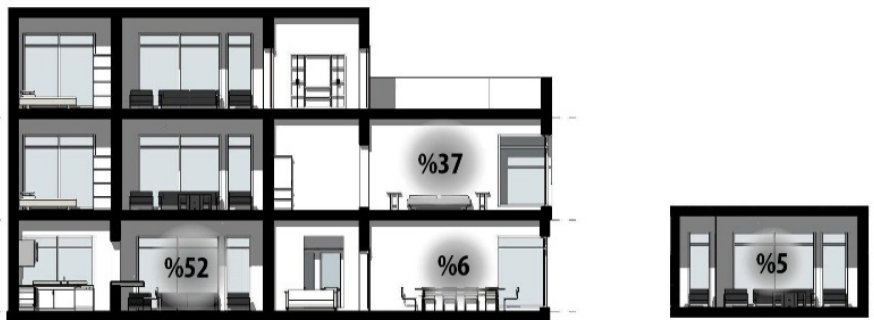

Duplex villa (cross section)

Figure 5. Workspace zone allocation within residences

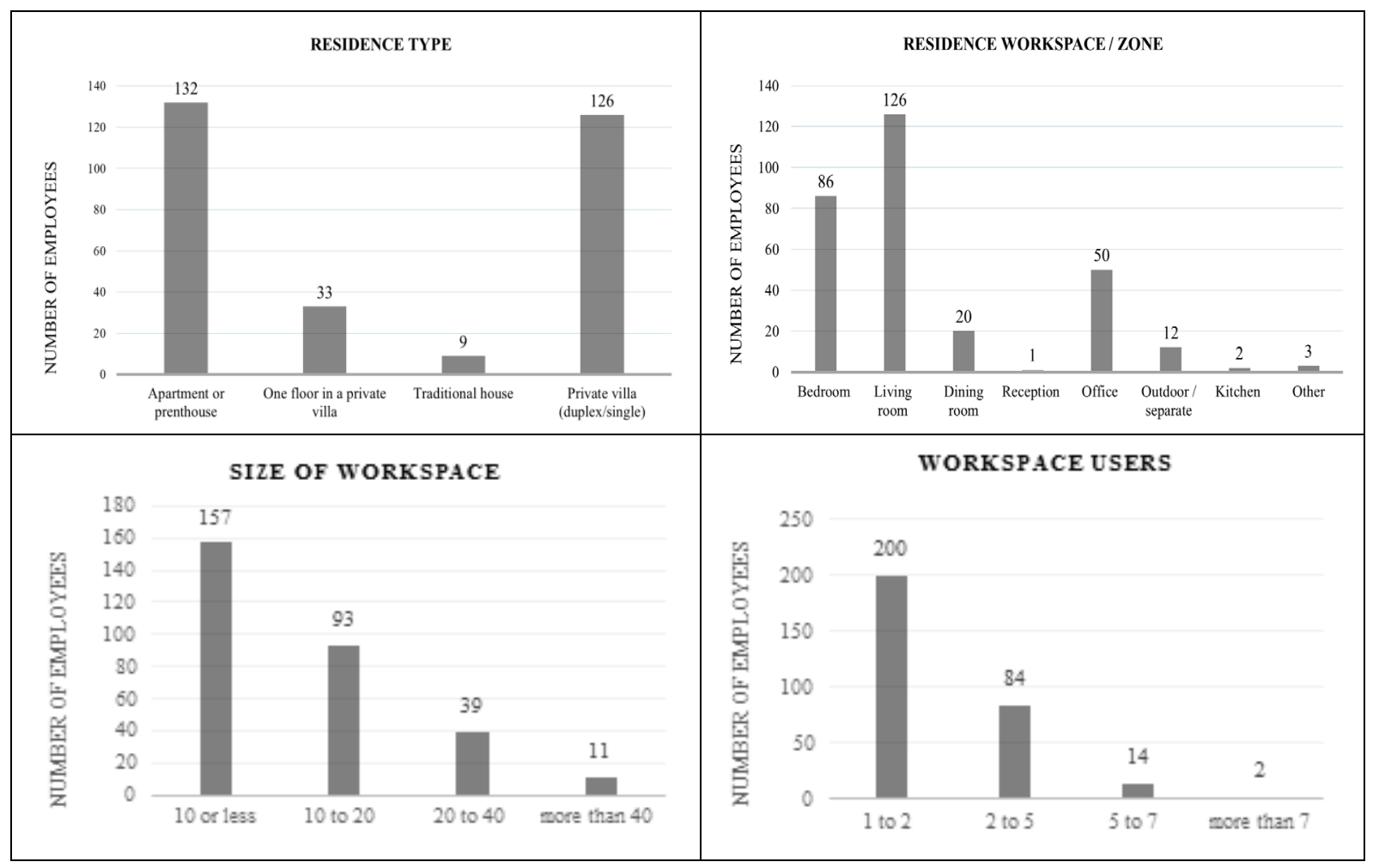




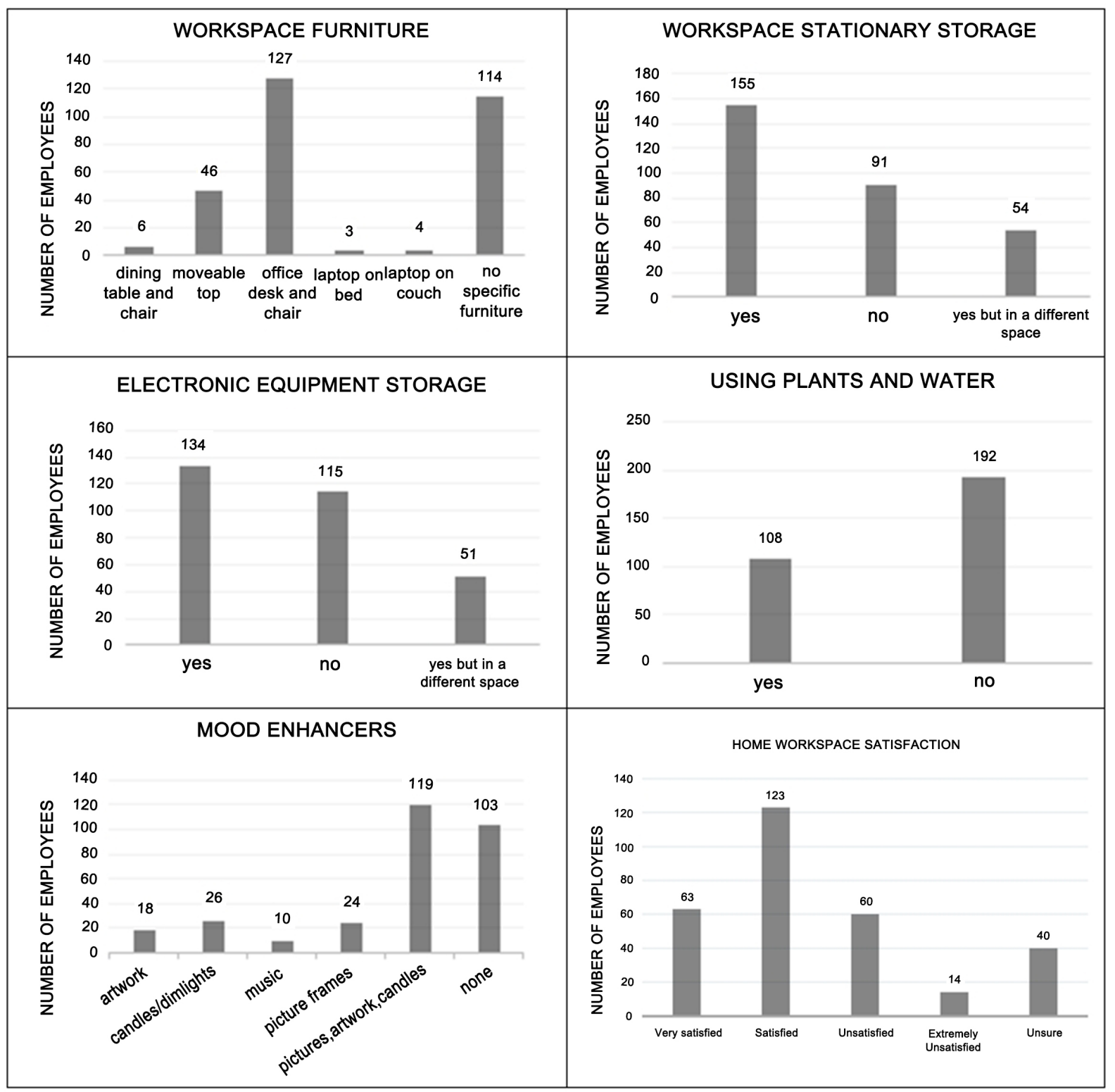

Figure 6. Section 2 trends: workspace design (during pandemic)

In total, 113 employees (38\%) worked less than 8 hours per week from home during the pandemic. A total of $49 \%$ worked continuously for 2-4 hours in their home workspace; a significant trend is that most employees working from home in Saudi did not work for long, uninterrupted hours. In total, $42 \%$ mainly used technology (internet and computers) while working remotely. In general, 189 out of $300(63 \%)$ employees were satisfied with their work productivity from home, delivering either the same amount of work or more. This again forms a significant trend in the direct analysis. Figures 7 illustrate these trends. 


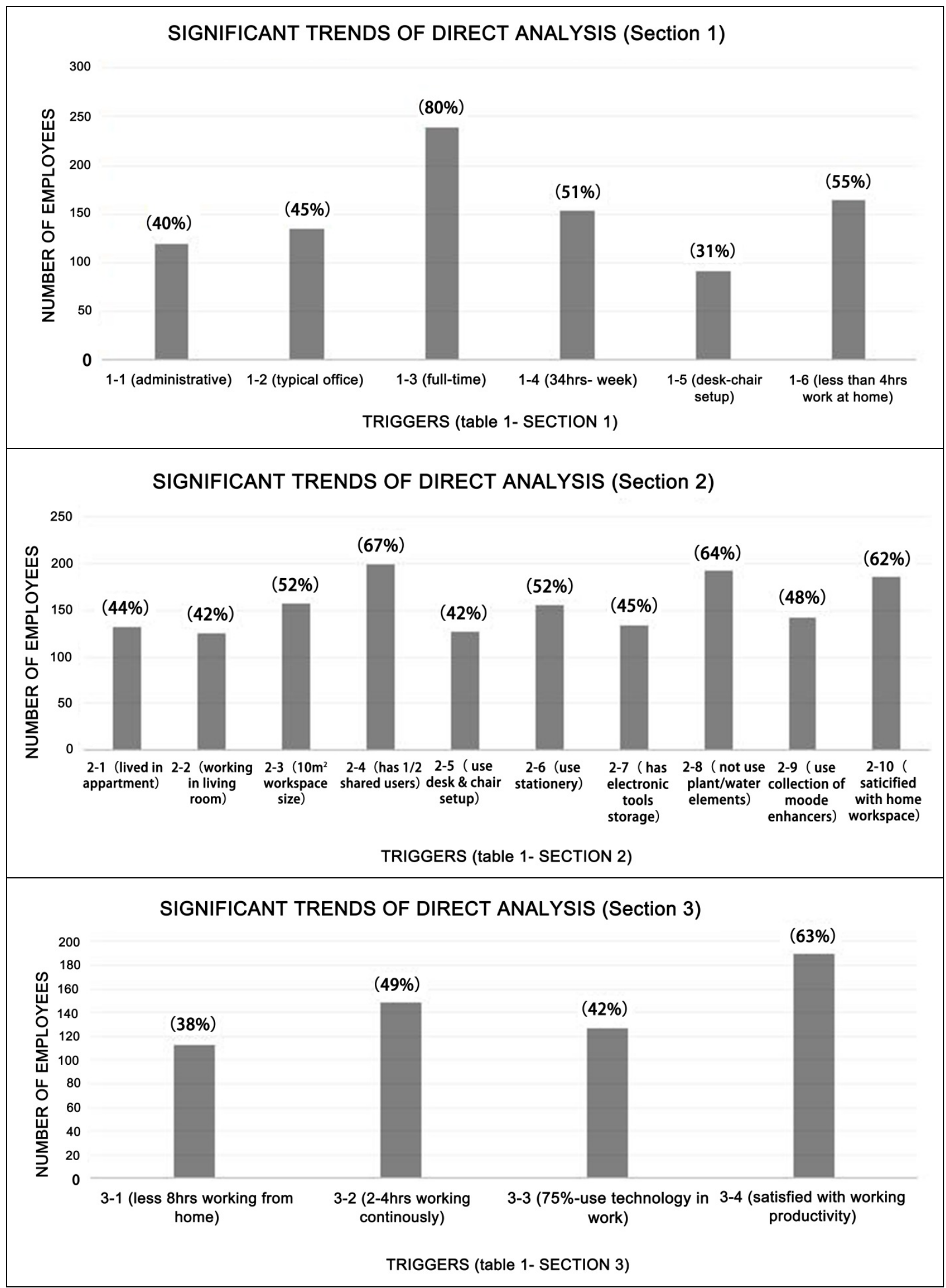

Figure 7. Significant trends from direct analysis (Table 1) 


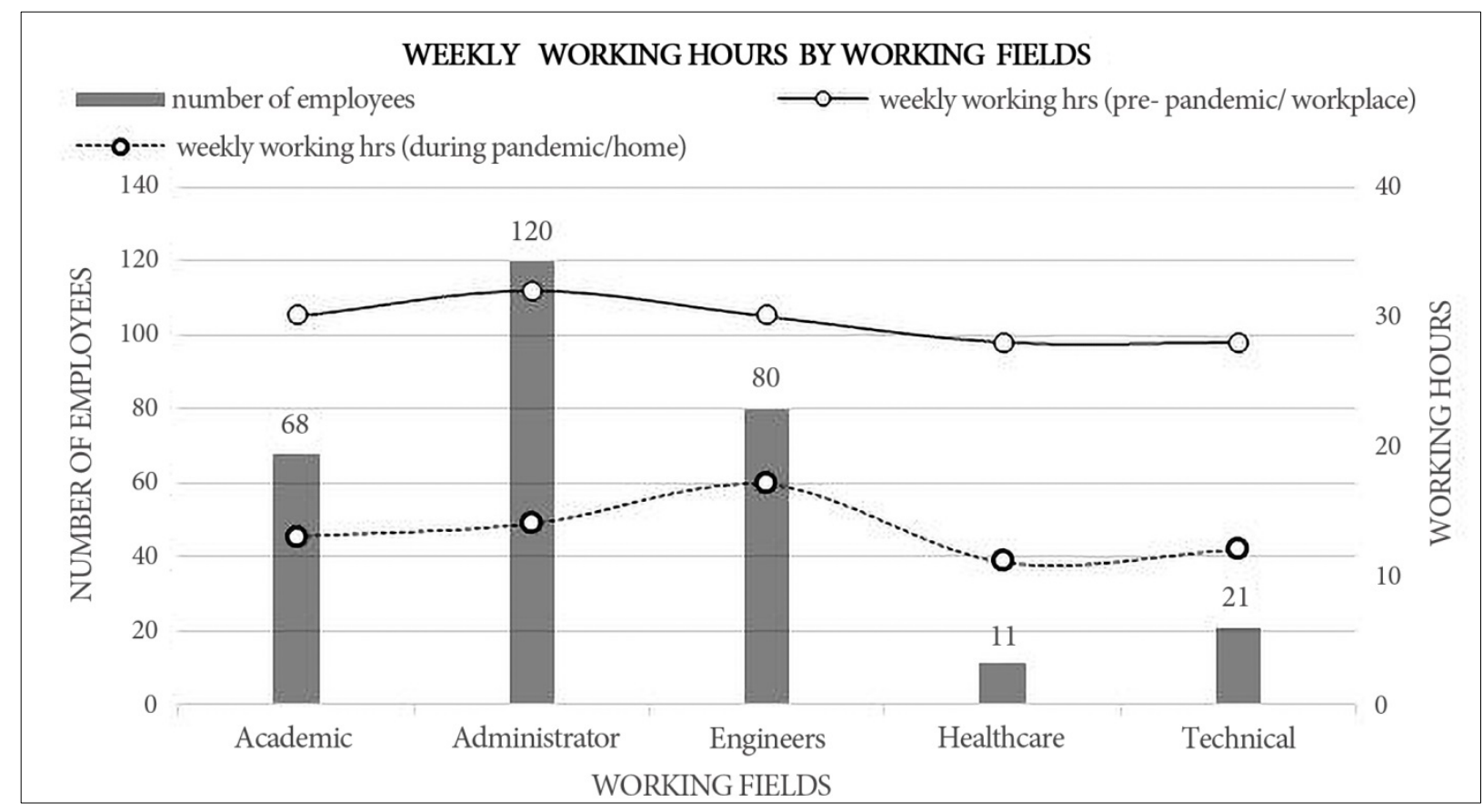

Figure 8. Theme A: Cross-sectional analysis

\subsection{Indirect Analysis: Cross-sectional Trends from the Data}

In this discussion, three main themes (A, B, and C), each with a number of triggers, were used to link data in the cross-sectional approach (Table 1). The emerged concepts will help prepare Saudi homes for working in lockdowns or for any development that will require a change in working style.

\subsubsection{Theme A:}

Theme A comprises a comparison of working schemes, normal routine vs lockdown, linked to productivity levels (Triggers 1-1, 1-4, 3-1). Figure 9 compares the normal weekly working hours schemes vs weekly working hours during the pandemic of employees participating in the study. Administrators showed the highest weekly working hours in normal working schemes (pre-pandemic); however, there was a significant drop, as illustrated, when they worked from home. Engineers, on the contrary, showed the highest working hours during the pandemic, and showed a smaller gap between the two schemes (pre vs during pandemic). The significant drop in working hours illustrated in Figure 9 could be because the majority prefer homes for living and pleasure rather than for work. Nevertheless, this pandemic proved the requirement for improved conceptualisations of home design to accommodate all requirements and aspects of life (e.g. working, studying, and leisure).

\subsubsection{Theme B:}

Theme B compares two themes: it examines the responses of same/better/much better productivity when working in lockdown, linked to working fields and home workspace designs versus responses showing less productivity when working in lockdown, linked to working fields and home workspace designs (Triggers 1-1, Sections 2, 3-4).

For all participants, 189 out of 300 were satisfied with their productivity levels working from home, believing they worked either the same, better, or much better than during their usual routines. This raises the question: What are the main reasons, in terms of home characteristics, that cause them to believe that they work well remotely? This trend led to an examination of another theme; the furniture and mood enhancers of employees who were satisfied with working from home or who produced similar work levels versus those who thought they worked less from home. Including all working styles (part-time, full-time, freelancing), 153 out of 300 worked more than $34 \mathrm{hrs}$ per week originally, but during the lockdown, only 36 of them worked more than $36 \mathrm{hrs}$ in 1 week, and only 86 believed they worked the same or better, or much better (Figure 10 and Table 2). 


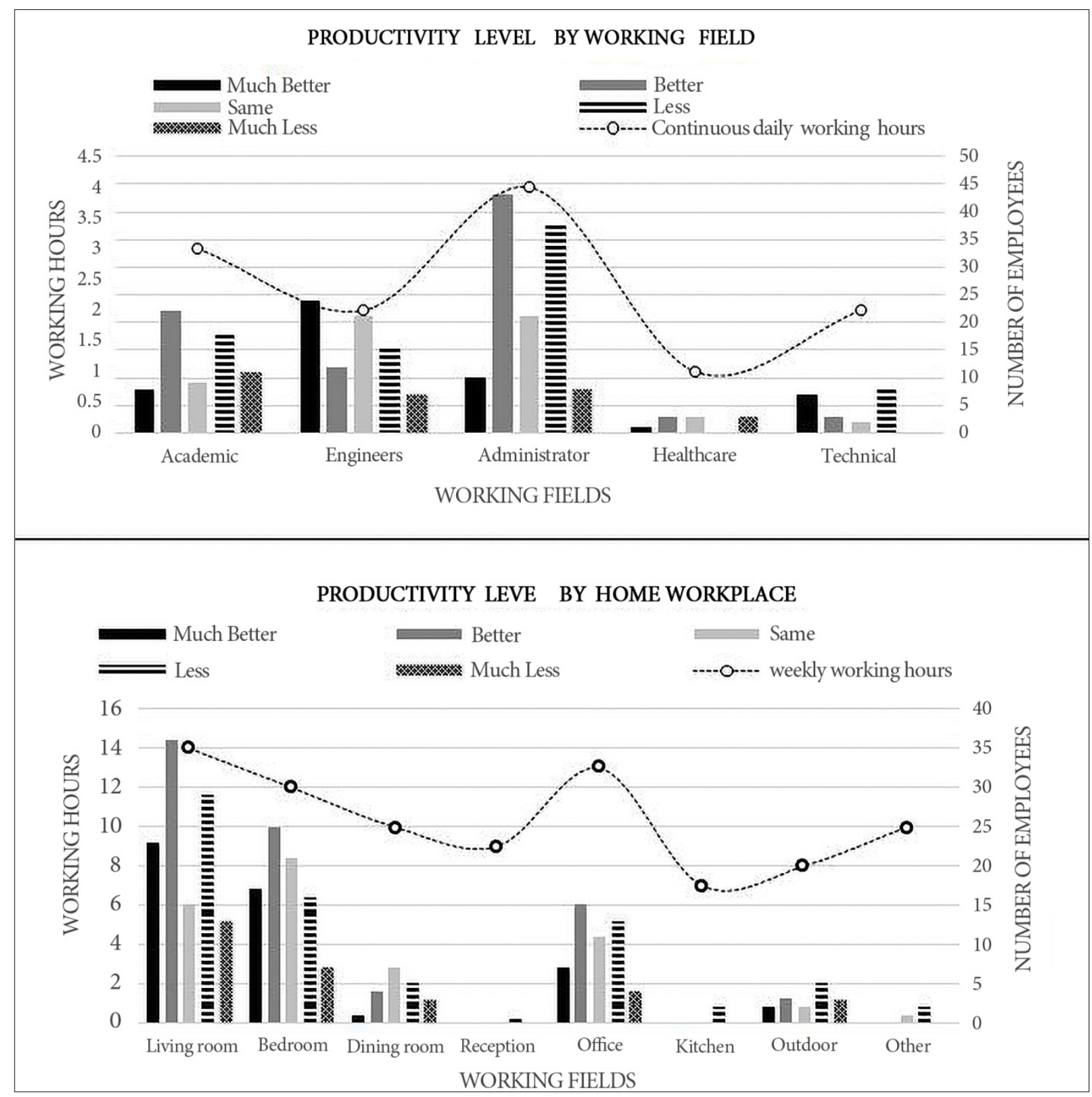

Figure 9. Theme B: Cross-sectional analysis 
Table 2. Saudi employees working from home - comparison by thematic approach of design vs productivity levels

\begin{tabular}{|c|c|c|}
\hline Design Aspect & $\begin{array}{c}\begin{array}{c}\text { Productivity levels: Same/better/much better } \\
\text { productivity } \\
(189)\end{array} \\
\end{array}$ & $\begin{array}{c}\text { Productivity levels: } \\
\text { less/much less productivity } \\
\text { (111) } \\
\end{array}$ \\
\hline Working zone & $\begin{array}{l}97 \text { lived in apartments, penthouses, or a floor in villas } \\
84 \text { lived in villas } \\
8 \text { lived in primitive houses }\end{array}$ & $\begin{array}{l}68 \text { lived in apartments, penthouses, or a floor in villas } \\
42 \text { lived in villas } \\
1 \text { lived in primitive houses }\end{array}$ \\
\hline Space & $\begin{array}{l}74 \text { worked in the living room } \\
63 \text { worked in bedrooms } \\
33 \text { worked in office spaces } \\
12 \text { worked in the dining room } \\
7 \text { worked in outdoor spaces or separate majlis }\end{array}$ & $\begin{array}{l}52 \text { worked in the living room } \\
23 \text { worked in bedrooms } \\
17 \text { worked in office spaces } \\
8 \text { worked in the dining room } \\
5 \text { worked in outdoor spaces or separate majlis } \\
3 \text { worked in different spaces - no specific } \\
2 \text { worked in kitchen } \\
1 \text { worked in the reception }\end{array}$ \\
\hline Area & $\begin{array}{l}99 \text { worked in } 10 \text { sq. metres or less } \\
53 \text { worked in } 10-20 \text { sq. metres } \\
29 \text { worked in } 20-40 \text { sq. metres } \\
8 \text { worked in } 40 \text { sq. metres or more }\end{array}$ & $\begin{array}{l}58 \text { worked in } 10 \text { sq. metres or less } \\
40 \text { worked in } 10-20 \text { sq. metres } \\
10 \text { worked in } 20-40 \text { sq. metres } \\
3 \text { worked in } 40 \text { sq. metres or more }\end{array}$ \\
\hline Adjacency & $\begin{array}{l}104 \text { worked next to the living room } \\
42 \text { worked next to bedroom } \\
23 \text { worked next to reception } \\
10 \text { worked in a separate floor or space only for work } \\
\text { (office) } \\
10 \text { worked next to dining room }\end{array}$ & $\begin{array}{l}70 \text { worked next to the living room } \\
14 \text { worked next to bedroom } \\
11 \text { worked next to dining room } \\
11 \text { worked next to reception } \\
5 \text { worked in a separate floor or space only for work } \\
\text { (office) }\end{array}$ \\
\hline Other users & $\begin{array}{l}129 \text { worked without sharing spaces or shared with one } \\
\text { user only } \\
49 \text { shared spaces with } 3-5 \text { people } \\
9 \text { shared spaces with } 5-7 \text { people } \\
2 \text { shared spaces with more than } 7 \text { people }\end{array}$ & $\begin{array}{l}71 \text { worked without sharing spaces or shared with one } \\
\text { user only } \\
35 \text { shared spaces with } 3-5 \text { people } \\
5 \text { shared spaces with } 5-7 \text { people }\end{array}$ \\
\hline Furniture & $\begin{array}{l}88 \text { used desks and chairs } \\
60 \text { no specific furniture to work at home } \\
34 \text { used mobile tops/surfaces } \\
4 \text { used dining tables and chairs } \\
3 \text { worked on the sofa }\end{array}$ & $\begin{array}{l}54 \text { no specific furniture to work at home } \\
39 \text { used desks and chairs } \\
12 \text { used mobile tops/surfaces } \\
3 \text { worked on bed } \\
2 \text { used dining tables and chairs } \\
1 \text { worked on the sofa }\end{array}$ \\
\hline Storage & $\begin{array}{l}111 \text { stored stationery in a specific place in their work } \\
\text { zone } \\
41 \text { did not have specific places for stationery at home } \\
37 \text { stored stationery in different places at home } \\
98 \text { had specific places at their home workspace for } \\
\text { electronics tools } \\
65 \text { did not have specific places for electronics } \\
26 \text { stored electronics in different places at home }\end{array}$ & $\begin{array}{l}50 \text { did not store stationery at home } \\
44 \text { stored stationery in a specific place in their work zone } \\
17 \text { stored stationery in different places at home } \\
50 \text { did not have specific places for electronics } \\
36 \text { had specific places at their home workspace for } \\
\text { electronics tools } \\
25 \text { stored electronics in different places at home }\end{array}$ \\
\hline Mood enhancers & $\begin{array}{l}69 \text { used water elements or plants, } 120 \text { did not } \\
95 \text { used a mix of artwork, pictures, and artwork } \\
52 \text { did not use any mood enhancers } \\
14 \text { used artwork they usually collect } \\
10 \text { used candles or dim lights } \\
5 \text { used sound systems or played music } \\
13 \text { used picture frames with memories } \\
\end{array}$ & $\begin{array}{l}39 \text { used water elements or plants, } 72 \text { did not } \\
44 \text { used a mix of artwork, pictures, and artwork } \\
31 \text { did not use any mood enhancers } \\
16 \text { used candles or dim lights } \\
11 \text { used picture frames with memories } \\
5 \text { used candles or dim lights } \\
4 \text { used artwork they usually collect } \\
\end{array}$ \\
\hline $\begin{array}{c}\text { Satisfaction level } \\
\text { of all above design } \\
\text { aspects }\end{array}$ & $\begin{array}{l}136 \text { were satisfied or very satisfied } \\
18 \text { were not satisfied or extremely unsatisfied } \\
35 \text { were not sure }\end{array}$ & $\begin{array}{l}50 \text { were satisfied or very satisfied } \\
39 \text { were not satisfied or extremely unsatisfied } \\
22 \text { were not sure }\end{array}$ \\
\hline
\end{tabular}

\subsubsection{Theme C:}

Theme $\mathrm{C}$ considered preferred working zones at home and linked trends to most used furniture types and working hours (daily and weekly) during lockdown with employees' productivity levels (Triggers 2-2, 2-5, 3-2, 3-4).

We examined the types of furniture used, which category of employee used each type, the length of time the furniture was used continuously for and in which part of the house, in addition to general productivity levels. The reason for this designed theme was to identify the most preferable zones to work and the types of furniture used in these zones, linked to comfort that was measured or indicated by the number of continuous working hours. Figure 11 illustrates all three triggers (2-5, 3-2, 3-4), showing better productivity levels when using desks and chairs at home for long working hours. However, there was 
a strong trend showing that employees using moveable tops or not using specific types of furniture were still satisfied with productivity when working from home. Looking for other solutions when working from home thus emerged as a concept. Table 4 presents the detailed data of triggers 2-2 and 2-5, linked to triggers 3-2 and 3-4.



Figure 10. Theme C: Cross-sectional analysis

Table 3. Saudi employees working from home - furniture used, users, and locations in home

\begin{tabular}{|c|c|c|c|}
\hline $\begin{array}{c}\text { Furniture } \\
\text { (all } 300 \text { participants) }\end{array}$ & Background/specialty & $\begin{array}{c}\text { Working hours in } \\
\text { lockdown/continuously in } \\
\text { one day }\end{array}$ & Working zone/space in lockdown \\
\hline $\begin{array}{l}\text { Typical: } \\
\text { Desk-chair } \\
\text { (127) }\end{array}$ & $\begin{array}{c}47 \text { engineering } \\
39 \text { academia } \\
34 \text { administration } \\
4 \text { healthcare } \\
3 \text { technical }\end{array}$ & $\begin{array}{c}\text { Engineering (47): } \\
21 \text { worked for } 2-4 \mathrm{hrs} \\
17 \text { worked less than } 2 \mathrm{hrs} \\
7 \text { worked for } 4-6 \mathrm{hrs} \\
2 \text { worked more than } 6 \mathrm{hrs} \\
\text { Academia (39): } \\
22 \text { worked for } 2-4 \mathrm{hrs} \\
10 \text { worked less than } 2 \mathrm{hrs} \\
6 \text { worked for } 4-6 \mathrm{hrs} \\
1 \text { worked more than } 6 \mathrm{hrs} \\
\text { Administration ( } 34): \\
19 \text { worked for } 2-4 \mathrm{hrs} \\
9 \text { worked for } 4-6 \mathrm{hrs} \\
2 \text { worked or less than } 2 \mathrm{hrs} \\
2 \text { worked more than } 6 \mathrm{hrs} \\
\\
\text { Healthcare }(4): \\
3 \text { worked for } 2-4 \mathrm{hrs} \\
1 \text { worked less than } 2 \mathrm{hrs} \\
\\
\text { Technical }(3): \\
2 \text { worked for } 2-4 \mathrm{hrs} \\
1 \text { worked less than } 2 \mathrm{hrs}\end{array}$ & $\begin{array}{c}\frac{\text { Engineering }(47):}{16 \text { office }} \\
14 \text { bedroom } \\
1 \text { dining room } \\
14 \text { living room } \\
1 \text { reception } \\
1 \text { outdoor space or separate majlis } \\
\frac{\text { Academia (39): }}{15 \text { office }} \\
11 \text { living room } \\
10 \text { bedroom } \\
2 \text { dining room } \\
1 \text { different space at home } \\
\text { Administration }(34): \\
12 \text { bedroom } \\
10 \text { living room } \\
11 \text { office } \\
1 \text { outdoor space or separate majlis } \\
\text { Healthcare }(4): \\
3 \text { bedroom } \\
1 \text { living room } \\
\frac{\text { Technical }(3):}{1 \text { living room }} \\
1 \text { bedroom } \\
1 \text { office }\end{array}$ \\
\hline
\end{tabular}


Table 3 Continued

\begin{tabular}{|c|c|c|c|}
\hline $\begin{array}{l}\text { No specific furniture } \\
\qquad(114)\end{array}$ & $\begin{array}{l}64 \text { administration } \\
20 \text { academia } \\
14 \text { engineering } \\
9 \text { technical } \\
7 \text { healthcare }\end{array}$ & $\begin{array}{c}\text { Administration (64): } \\
39 \text { worked for } 2-4 \mathrm{hrs} \\
17 \text { worked less than } 2 \mathrm{hrs} \\
6 \text { worked for } 4-6 \mathrm{hrs} \\
2 \text { worked more than } 6 \mathrm{hrs} \\
\text { Academia (20): } \\
10 \text { worked less than } 2 \mathrm{hrs} \\
6 \text { worked } 2-4 \mathrm{hrs} \\
4 \text { worked } 4-6 \mathrm{hrs} \\
\text { Engineering }(14): \\
5 \text { worked for } 2-4 \mathrm{hrs} \\
5 \text { worked less than } 2 \mathrm{hrs} \\
3 \text { worked more than } 6 \mathrm{hrs} \\
1 \text { worked for } 4-6 \mathrm{hrs} \\
\\
\text { Technical }(9): \\
5 \text { worked less than } 2 \mathrm{hrs} \\
3 \text { worked for } 2-4 \mathrm{hrs} \\
1 \text { worked } 4-6 \mathrm{hrs} \\
\text { Healthcare }(7): \\
4 \text { worked } 2-4 \mathrm{hrs} \\
3 \text { worked less than } 2 \mathrm{hrs}\end{array}$ & $\begin{array}{c}\frac{\text { Administration }(64):}{34 \text { living room }} \\
18 \text { bedroom } \\
5 \text { outdoor spaces or separate majlis } \\
4 \text { dining room } \\
2 \text { kitchen } \\
1 \text { different space at home } \\
\text { Engineering (14): } \\
6 \text { living room } \\
3 \text { bedroom } \\
3 \text { dining room } \\
2 \text { outdoor spaces or separate majlis } \\
\frac{\text { Academia }(20):}{15 \text { living room }} \\
2 \text { dining room } \\
2 \text { office space } \\
1 \text { bedroom } \\
\text { Technical }(9): \\
8 \text { living room } \\
1 \text { bedroom } \\
\frac{\text { Healthcare }(7):}{4 \text { living room }} \\
2 \text { bedroom } \\
1 \text { dining room }\end{array}$ \\
\hline $\begin{array}{l}\text { Moveable foldable } \\
\text { top/surface } \\
\text { (46) }\end{array}$ & $\begin{array}{l}17 \text { engineering } \\
14 \text { administration } \\
8 \text { academia } \\
7 \text { technical }\end{array}$ & $\begin{array}{c}\frac{\text { Engineering }(17):}{7 \text { worked } 2-4 \mathrm{hrs}} \\
4 \text { worked } 4-6 \mathrm{hrs} \\
5 \text { worked less than } 2 \mathrm{hrs} \\
1 \text { worked more than } 6 \mathrm{hrs} \\
\text { Administration (14): } \\
7 \text { worked less than } 2 \mathrm{hrs} \\
6 \text { worked 2-4 hrs } \\
1 \text { worked } 4-6 \mathrm{hrs} \\
\text { Academia (8): } \\
6 \text { worked for } 2-4 \mathrm{hrs} \\
1 \text { worked for } 4-6 \mathrm{hrs} \\
1 \text { worked for less than } 2 \mathrm{hrs} \\
\text { Technical (7): } \\
6 \text { worked less than } 2 \mathrm{hrs} \\
1 \text { worked more than } 6 \mathrm{hrs}\end{array}$ & $\begin{array}{c}\frac{\text { Engineering }(17):}{5 \text { office }} \\
4 \text { bedroom } \\
3 \text { living room } \\
2 \text { dining room } \\
1 \text { different space at home } \\
2 \text { outdoor spaces or separate majlis } \\
\text { Administration }(14): \\
7 \text { living room } \\
6 \text { bedroom } \\
1 \text { dining room } \\
\frac{\text { Academia }(8):}{4 \text { living room }} \\
4 \text { bedroom } \\
\text { Technical }(7): \\
6 \text { living room } \\
1 \text { bedroom }\end{array}$ \\
\hline $\begin{array}{c}\text { Dining tables } \\
\text { (6) }\end{array}$ & $\begin{array}{c}4 \text { administration } \\
1 \text { academic } \\
1 \text { technical }\end{array}$ & $\begin{array}{c}\text { Administration (4): } \\
2 \text { worked } 4-6 \mathrm{hrs} \\
1 \text { worked } 2-4 \mathrm{hrs} \\
1 \text { worked less than } 2 \mathrm{hrs} \\
\text { Academia (1): } \\
1 \text { worked } 4-6 \mathrm{hrs} \\
\frac{\text { Technical (1): }}{1 \text { worked } 2-4 \mathrm{hrs}}\end{array}$ & $\begin{array}{c}\frac{\text { Administration }(4):}{2 \text { dining room }} \\
1 \text { living room } \\
1 \text { outdoor space or separate majlis } \\
\frac{\text { Academia }(1):}{1 \text { dining room }} \\
\frac{\text { Technical }(1):}{1 \text { dining room }}\end{array}$ \\
\hline $\begin{array}{l}\text { On sofa } \\
\text { (4) }\end{array}$ & $\begin{array}{c}2 \text { engineering } \\
1 \text { administration } \\
1 \text { technical }\end{array}$ & $\begin{array}{c}\frac{\text { Engineering (2): }}{2 \text { worked 2-4 hrs }} \\
\frac{\text { Administration (1): }}{1 \text { worked less than } 2 \mathrm{hrs}} \\
\frac{\text { Technical (1): }}{1 \text { worked 2-4 hrs }}\end{array}$ & $\begin{array}{l}\frac{\text { Engineering (2): }}{2 \text { bedroom }} \\
\frac{\text { Administration (1): }}{1 \text { living room }} \\
\frac{\text { Technical (1): }}{1 \text { bedroom }}\end{array}$ \\
\hline $\begin{array}{l}\text { On bed } \\
\text { (3) }\end{array}$ & 3 administration & $\begin{array}{l}\text { Administration (3): } \\
2 \text { more than } 6 \mathrm{hrs} \\
1 \text { less than } 2 \mathrm{hrs}\end{array}$ & $\frac{\text { Administration (3): }}{3 \text { bedroom }}$ \\
\hline
\end{tabular}


While Theme A showed a drop in weekly working hours, Themes $\mathrm{B}$ and $\mathrm{C}$ emerged as significant concepts. As previously discussed, the direct analysis (Figure 6) shows the trend that the typical furniture used to work from home was a desk and chair, with a significant number also reporting that they used no specific type of furniture. This was then linked to different employment backgrounds, with engineers, academics, and administrative workers showing their requirement for the use desks and chairs. Another trend occurred where administrators used a variety of different furniture, as illustrated in Table 3. Additionally, a flexible and affordable type of furniture (moveable/foldable table-top or surface) was used. Its use and ergonomic aspects to accommodate additional working hours and productivity could be investigated and studied further as an option for future research. Storage issues should also be considered (storing of stationery and important electronic equipment). Office spaces and living rooms emerged as a clear trend in terms of working from home zones, whereas the highest trends observed from the data (trigger 2-2) were that $42 \%$ worked from the living room and 29\% worked from the bedroom. These conflicting trends highlight the requirement to look at easier solutions for working from home, which we consider an emerged concept. Moreover, the fact that continuous work lasted mostly for only 2-4 hrs (trigger 3-2) for most furniture types highlights the requirement for studies into ergonomics and comfort for longer and more comfortable working hours. The emerged concepts prove that it is not only typical desk-chair setups that are the ultimate or the best solutions for a person's comfort and productivity.

\section{Conclusions}

The previous section summarises how concepts emerged through a series of data analyses; however, it is not an easy task to request employees to change or rezone spaces in their homes to improve their work performance. Home is mainly meant to be for living, but the pandemic has changed a lot of our perceptions about life and working from home is one of them. Direct and indirect analyses and emerged concepts from the data allowed us to propose a series of solutions for improved productivity while working fully or partially from home. This can lead the way for Saudi employees to rethink their living spaces and their readiness to work from home.

We suggest minor additions and changes to existing setups in which employees already work well. The recommendations include four categories for future research (regardless of the type of home or working zone) to rethink working from home in Saudi Arabia.

\subsection{Category 1}

This concerns additive elements to existing working spaces that already have desks and chairs dedicated to working at home. A series of privacy and mood enhancers for current working zones and setups are required to increase satisfaction. This includes elements such as partitions, privacy enhancers, and additive customisation of shared zones such as living rooms. A study on the acoustics of this aspect is required.

\subsection{Category 2}

This regards units and kits to facilitate working flexibly in any zone at home. An exploratory design process is necessary to produce flexible and affordable kits, units, and products to work flexibly anywhere (mainly at home). This includes enhancing mobile work tops and surfaces such as the foldable tops mentioned in this study's trends.

\subsection{Category 3}

Recommendations resulting from research into better home desk and chair options and the overall interior context are required. Exploratory research and three-dimensional testing of setups should be undertaken. This may include examining colours, textures, patterns, material technologies, and ergonomic studies regarding the comfort of the desk setup in relation to interior well-being. It is also important to examine acoustics from this perspective.

\subsection{Category 4}

The indoor quality of houses in Saudi Arabia in relation to the requirements of working from home is to be analysed and improved. Exploratory research should be undertaken into natural vs artificial lighting, air, and acoustics as well as the home workspace zone. The flow of users and furniture pieces in the typical home layout must form part of this.

In order to conduct future data collection and form the recommended design teams, a list of keywords was used to pre-rate each suggested category so that the situation can be addressed quickly, and weightings from the data of this study were added as links. Keywords that meet our assumptions are ticked in Table 4. In the table, affordability refers to how affordable it might be for the current Saudi employee to implement the solution; flexibility refers to the solution itself in accordance with current home setups; functionality regards the level to which it accommodates the function of work, multi-functionality indicates that it can offer more than one use/function; and lastly, the adaptability level of transformation or change is indicated. 
Table 4. Saudi employees working from home - future solutions and implementation levels from the data

\begin{tabular}{|c|c|c|c|c|c|c|}
\hline Category & Affordability & Flexibility & Functionality & Multi-functionality & Adaptability & Concepts linked to this study \\
\hline $\begin{array}{c}\text { Category 1: } \\
\text { Additives }\end{array}$ & $\sqrt{ }$ & $\sqrt{ }$ & & $\sqrt{ }$ & $\sqrt{ }$ & $\begin{array}{l}\text { Triggers 2-9, 2-10 resulted in } \\
\text { good responses of users. } \\
\text { Majority in Theme B showed } \\
\text { uses of mood enhancers, } \\
\text { especially people who felt they } \\
\text { have worked productively. }\end{array}$ \\
\hline $\begin{array}{c}\text { Category 2: } \\
\text { Units/kits }\end{array}$ & & $\sqrt{ }$ & $\sqrt{ }$ & & $\sqrt{ }$ & $\begin{array}{l}\text { Working from living room, } \\
\text { bedroom, and anywhere in the } \\
\text { house emerged in this need } \\
\text { (Trigger 2-2 and Theme C). }\end{array}$ \\
\hline $\begin{array}{l}\text { Category 3: } \\
\text { Enhanced } \\
\text { home-office } \\
\text { furniture }\end{array}$ & & & $\sqrt{ }$ & & & $\begin{array}{l}\text { Working for fewer hours as a } \\
\text { trend continuously emerged in } \\
\text { the need for looking at furniture } \\
\text { ergonomics and usability } \\
\text { (Trigger } 2-5,3-2 \text {, and Theme } \\
\text { C). }\end{array}$ \\
\hline $\begin{array}{l}\text { Category } 4 \text { : } \\
\text { Zones and } \\
\text { indoor } \\
\text { quality }\end{array}$ & & & $\sqrt{ }$ & & & $\begin{array}{l}\text { Future triggers will be designed, } \\
\text { zoning shown in this study in } \\
\text { Triggers } 2-2,2-3 \text {, and 2-4. }\end{array}$ \\
\hline
\end{tabular}

Future recommendations and study results will be shared with the public and with design professionals to rate the requirement for these solutions and start acting. As shown in Table 4, the solution of Category 1 for future research ticks most of the boxes and might be the next step. Category 2 may be next, followed by Categories 3 and 4 . Additionally, all the above solutions must pay attention to ergonomics and usability, and should be tested in actual Saudi houses to measure adaptability, comfort, and productivity levels. A group of researchers should be formed in parallel to start generating ideas and testing them in a following stage.

It is also necessary to highlight the requirement for developing user-friendly software and infrastructure to enable organisations to act quickly and adapt remotely in any future circumstances. A study in 1996 by Charles Grantham foresaw the requirement to develop this aspect and discussed design principles for the virtual workplace [12]. Thus, there is an urgent requirement to start adapting in this highly demanding era. Individuals and organisations, in parallel, are required to examine both the home design where the work will be conducted as well as the virtual workplace.

\section{REFERENCES}

[1] World Health Organization (WHO), "Getting your workplace ready for COVID-19", WHO, https://www.who.int/docs/default-source/coronaviruse/getti ng-workplace-ready-for-covid-19.pdf (accessed June 8, 2020).

[2] World Health Organization (WHO), "Coronavirus disease 2019 (COVID-19): Situation Report - 88”, WHO, https://www.who.int/docs/default-source/coronaviruse/situat ion-reports/20200417-sitrep-88-

covid-191b6cccd94f8b4f219377bff55719a6ed.pdf (accessed June 8, 2020).

[3] Saudi Press Agency, "Kingdom's government decides to suspend attendance at workplaces in all government agencies for period of (16) days except for health, security, military and electronic security center", Saudi Press Agency, https://www.spa.gov.sa/viewstory.php?lang=en\&newsid=20 47989 (accessed July 3, 2020).

[4] DRC Analytics/Arabic Report, "Remote Work Report", Digital Research Corporation Today, https://www.drc.today /reports (accessed June 15, 2020).

[5] Ghaffarianhoseini A., AlWaer H., Omrany H., Ghaffarianhoseini A., Alalouch C., Clements-Croome D., J. Tookey, "Sick building syndrome: are we doing enough?," Architectural Science Review, vol. 61, no. 3, pp. 99-121, 2018. DOI: $10.1080 / 00038628.2018 .1461060$

[6] Gensler, "Back to the Office: Return Strategies for the Workplace and Office Buildings", Gensler, https://www.gensler.com/back-to-the-office (accessed May 22, 2020).

[7] Gensler, "U.S. Work from Home Survey 2020", Gensler, https://www.gensler.com/research-insight/workplace-survey s/us-work-from-home-survey/2020 (accessed May 22, 2020).

[8] Ipsen, Christine, et al. "Six Key Advantages and Disadvantages of Working from Home in Europe during COVID-19." International Journal of Environmental Research and Public Health 18.4 (2021)

[9] General Authority for Statistics, "Housing Statistics 2018", General Authority for Statistics (Kingdom of Saudi Arabia), https://www.stats.gov.sa/sites/default/files/housing bulletin _semi_annual_2018_en.pdf (accessed July 4, 2020).

[10] Ministry of Housing, "Sakani Housing Program (2019), Ministry of Housing (Kingdom of Saudi Arabia), https://www.housing.gov.sa/ (accessed July 20, 2020). 
[11] Attiah D. Y., "A constant-theoretical sampling and comparison approach to optimise colour thinking in the interior-design process ( $\mathrm{PhD}$ thesis, University of Leeds)", White Rose eTheses Online, http://etheses.whiterose.ac.uk/1 3834/ (accessed).
[12] Grantham C. E., "Design principles for the virtual workplace," Proceedings of the 1996 ACM SIGCPR/SIGMIS Conference on Computer Personnel Research, Denver, CO, USA, April, pp. 12-21. DOI: $10.1145 / 238857.238862$ 